\title{
THE INFLUENCE OF CALCARENITE LIMESTONE REEFS ON BEACH EROSION AND RECOVERY, FROM SECONDS TO YEARS
}

\author{
Shari L. Gallop ${ }^{1}$, Cyprien Bosserelle ${ }^{1}$, Charitha B. Pattiaratchi ${ }^{1}$, Ian Eliot ${ }^{2}$ and Ivan D. Haigh ${ }^{3}$ \\ Mechanisms through which natural rock and coral landforms interact with waves, currents, sediment transport and \\ beach morphology are still poorly understood. Therefore, interactions between sediment transport and calcarenite \\ limestone landforms at Yanchep Lagoon in southwestern Australia were investigated over a cascade of spatial and \\ temporal scales: from single waves, through sea breeze and storm events, to seasonal and inter-annual variability. The \\ hypotheses that were confirmed included: (1) hard landforms with higher elevations relative to sea level are more \\ likely to reduce beach erosion but also to inhibit recovery; and (2) the placement and continuity of landforms in the \\ nearshore can generate current jets, and hence local sediment sources and sinks. These hypotheses were consistently \\ confirmed at all scales, however results show that to fully explain changes at broader scales (such as inter-annual and \\ seasonal changes) an understanding at finer scales (such as during sea breezes, storm event and single waves) was \\ necessary.
}

Keywords: perched beach; hard-bottom beach; rocky coast; multi-scale; sea level; waves; wind; littoral drift

\section{INTRODUCTION}

Hard coastal landforms such as rock and coral reefs are widespread and it is suggested that they have a significant influence on sediment transport (Rey et al. 2004; Muñoz-Perez and Medina, 2010). However, the mechanisms through which these landforms interact with sea level, waves, currents, and sediment supply are still relatively unknown. Some key processes that are likely to be important on perched beaches are summarized in Fig. 1a and include: obstacles in the nearshore trapping littoral drift; Aeolian sediment transport; development of scour-holes and sediment ramps on the seaward side of hard landforms; dampened offshore sediment flux; wave attenuation; current jets; resonance; and the possibility of a raised groundwater table inhibiting infiltration of water when waves run-up the beach leading to increased erosion. The often considerable alongshore variation in the topography of these landforms (Fig. 1b) adds an extra challenge for designing field experiments and numerical models to resolve this variability.

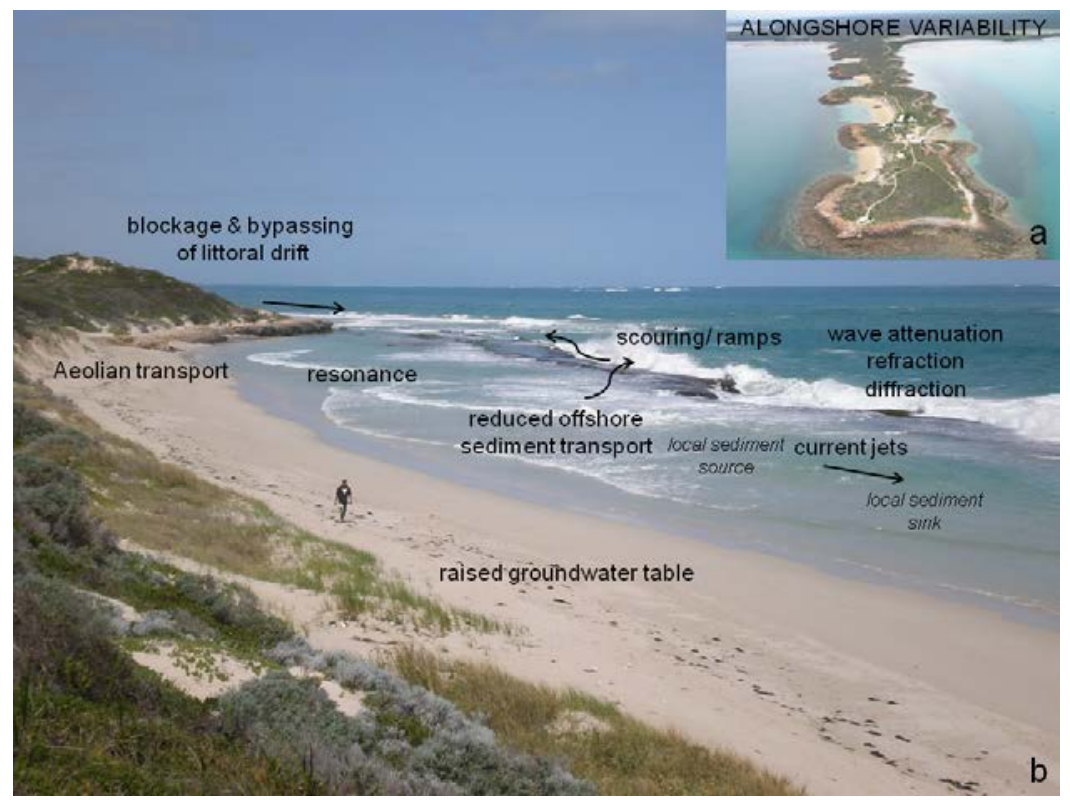

Figure 1. (a) potentially important processes on perched beaches; and (b) alongshore variability.

\footnotetext{
${ }^{1}$ School of Environmental Systems Engineering and the UWA Oceans Institute, The University of Western Australia, 35 Stirling Highway, Crawley, WA, 6009, Australia. shari.gallop@uwa.edu.au; bosserel@sese.uwa.edu.au; chari.pattiaratchi@uwa.edu.au

2 Damara WA, PO Box 1299, Innaloo, WA, 6018, Australia. ian.eliot@bigpond.com

${ }^{3}$ Ocean and Earth Science, National Oceanography Centre, University of Southampton, European Way, Southampton, SO14 3Z, UK. I.D.Haigh@soton.ac.uk
} 
Wave transformation, hydrodynamic circulation and sediment transport involves coupled processes at many spatial and temporal scales (Larson and Kraus 1995; Senechal et al. 2011). Moreover, sediment transport processes during calm conditions cannot necessarily be extrapolated to extreme conditions (Senechal et al. 2011). Therefore, interactions between sediment transport and the limestone landforms at Yanchep Lagoon in southwestern Australia were investigated over a cascade of spatial and temporal scales, during a variety of conditions including: (1) micro-scale (single waves); (2) meso-scale (storms and sea breezes); (3) macro-scale (seasons); and (4) mega-scale (years and decades). We hypothesised that hard landforms with a higher elevation relative to sea level would be more likely to reduce coastal erosion but also to inhibit recovery; and currents constricted by the hard landforms would play a key role in sediment transport by creating local sources and sinks of sediment.

\section{STUDY SITE}

Western Australia has a particularly high number of perched beaches due to coral, limestone and granitic substrates that outcrop at the coast. The study site was Yanchep Lagoon in southwestern Australia (Fig. 2a), where the beaches are perched on Pleistocene Tamala Limestone (Playford et al. 1975; Semeniuk and Johnson 1982). Calcarenite limestone outcrops offshore as shore-parallel reefs that are located up to $20 \mathrm{~km}$ from the coast (Fig. 2; Masselink and Pattiaratchi 2001). The beaches consist of well-sorted sand with $\mathrm{d}_{50}$ of $0.4 \mathrm{~mm}$ (Murphy 2011) made of mostly quartz and skeletal material (Semeniuk and Johnson 1982). The limestone topography varies alongshore with some of the beaches at Yanchep fronted to seaward by:

- $\quad$ limestone bluff that extends up to $0.4 \mathrm{~m}$ above Mean Sea Level (MSL) that seasonally impounds a coastal lagoon;

- $\quad$ continuous shore-parallel reef that is $0.3 \mathrm{~m}$ below MSL impounding a $20 \mathrm{~m}$-wide lagoon that closes with the beach to the south and is open to the north (Fig. 2b);

- a bombora located north of the lagoon exit that extends to $0.3 \mathrm{~m}$ below MSL (Fig. 2b). A bombora is a local term to define a small, shallow reef that creates a surf break;

- $\quad$ permanently-submerged, > 2 m deep patchy reef chain; and

- $\quad$ no outcrops, i.e. a sandy substrate to seaward.

At the northern end of the beach, the Club Capricorn groyne was built in 1971 and there are two sections of beach that are partially separated by a limestone headland; to the south of the headland the beach is perched on a limestone bluff and to north is it perched on submerged reef (Fig. 2b).

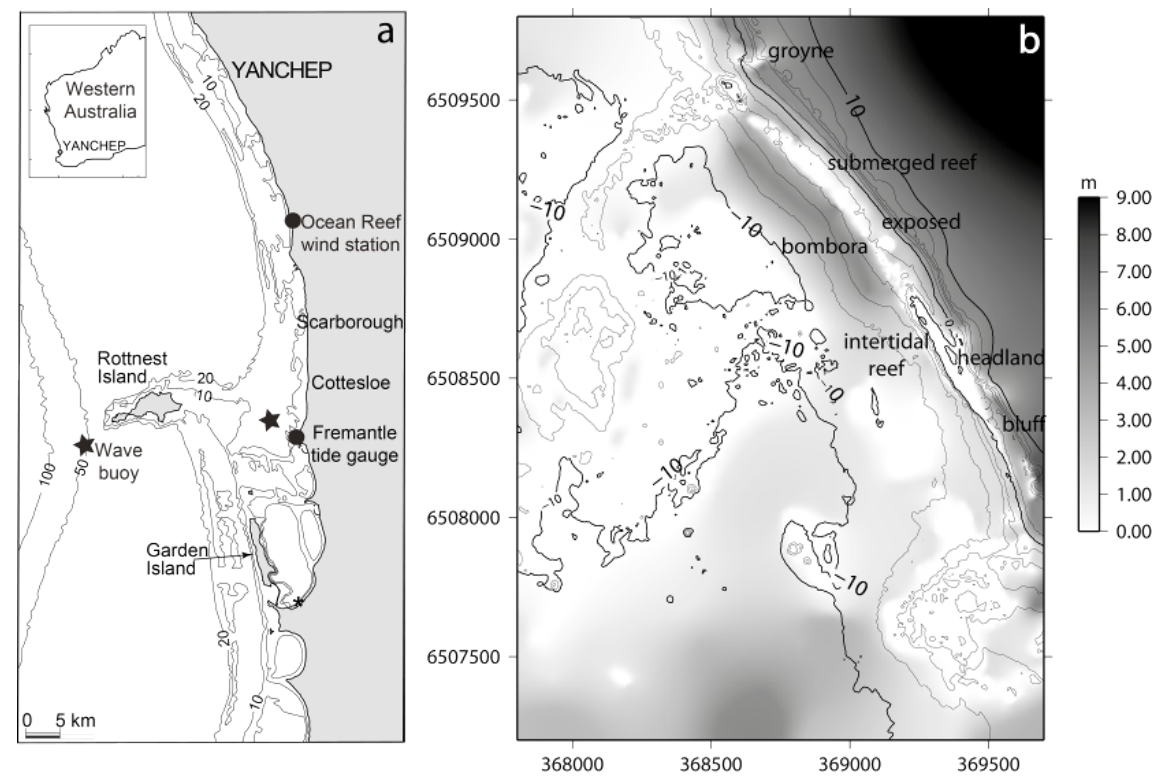

Figure 2. (a) The Perth Region; and (b) bathymetry contours of Yanchep Lagoon where the color bar indicates the estimated depth of sediment above the rock substrate in February 2010. White areas are limestone outcrops.

Southwestern Australia has three main wind seasons that are frequented by: (1) sea breezes; (2) low-pressure storms; and (3) high-pressure calm periods (Steedman and Craig 1983). Spring and summer (September to February) are dominated by strong and persistent south-southwest sea breezes of 
up to $20 \mathrm{~m} \mathrm{~s}^{-1}$ that blow obliquely-onshore at Yanchep which can generate 1 to $2 \mathrm{~m}$-high wind waves (Gallop et al. 2011a, b). A northerly flux of energy is driven by the wind waves generated by the sea breezes to create a longshore current (Gallop et al. 2012) and longshore sediment transport (Masselink 1996; Tonk 2004). Frontal storms can occur throughout the year but are more frequent as part of midlatitude depressions in winter from June to August with approximately 15 to 30 storms of 1 to 5 days in duration occurring annually (Verspecht and Pattiaratchi 2010). During these storms, wind speeds can reach $20 \mathrm{~m} \mathrm{~s}^{-1}$ and are generally southerly in summer and northwesterly in winter (Verspecht and Pattiaratchi 2010). In winter, significant wave height is 1.5 to $2 \mathrm{~m}$ (Lemm et al. 1999; Bosserelle et al. 2012) and it has been suggested that the direction of littoral drift reverses as a result of northwesterly storms (Kempin 1953; Masselink and Pattiaratchi 2001). High-pressure systems throughout the year (Gentilli 1972) and can last up to 15 days (Steedman and Craig 1983).

Southwestern Australia is microtidal with a mean spring tidal range of $0.6 \mathrm{~m}$ and MSL at the Fremantle Tide Gauge (Fig. 2a) is $0.8 \mathrm{~m}$ above chart datum (Department of Defence 2012). The Highest Astronomical Tide (HAT) is $1.4 \mathrm{~m}$ above the Lowest Astronomical Tide (LAT) which is at chart datum (Department of Defence 2012). Tides are strongly influenced by the 18.6 year lunar nodal cycle which has a range of approximately $0.1 \mathrm{~m}$ (Haigh et al. 2011a). Sea level has an annual cycle that averages $0.22 \mathrm{~m}$ in amplitude (Pattiaratchi and Eliot 2009) and also varies inter-annually, apparently in relation to the Southern Oscillation Index (SOI) which is a descriptor of of the El Niño-Southern Oscillation.

\section{METHODS}

Sediment transport at Yanchep Lagoon was investigated over nested spatial and temporal scales using a variety of methods. From 1970 to 2012 inter-annual and decadal changes were quantified using aerial photos (Fig. 3a) and intensive monitoring was undertaken from 2010 to 2012 to investigate changes during seasons, months, and sea breeze and storm events (Fig. 3b). Wind was measured $10 \mathrm{~m}$ above the ground at Ocean Reef; offshore waves were measured near Rottnest Island; and sea level was measured at Fremantle (Fig. 2a). Below we present a summary of the methodology.

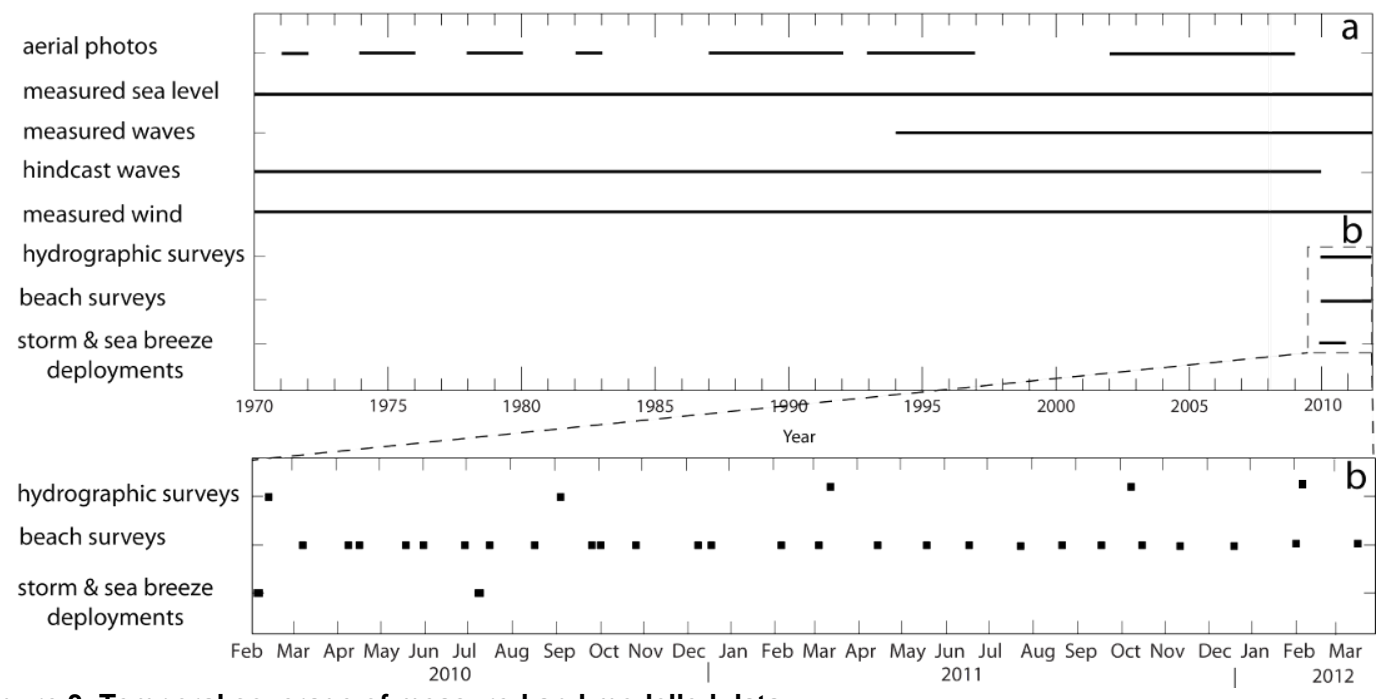

Figure 3. Temporal coverage of measured and modelled data.

\section{Inter-annual and Decadal Behavior}

Aerial photos were taken sporadically from 1971 to 2009 (Fig. 3a) between October and March. Vegetation lines and instantaneous shorelines were digitized from the photos (Fig. 4) to represent the upper and lower limits of the backshore, as defined by Komar (1998). The shoreline was approximated by the instantaneous water line as defined by Morton and McKenna (1999) and Boak and Turner (2005). Due to the low tidal range, it was not necessary to take into account the tidal level in the images. Errors inherent in the procedure summed to $\pm 7.5 \mathrm{~m}$ as a worst case in older images. In this paper, we focus on six transects (Fig. 4) and their behavior compared to annual indices of wind (Eliot and Travers 2011), waves hindcast by Bosserelle et al. (2012), and sea level separate into its three components of MSL, tide and surge by Haigh et al. (2010, 2011a, b). 


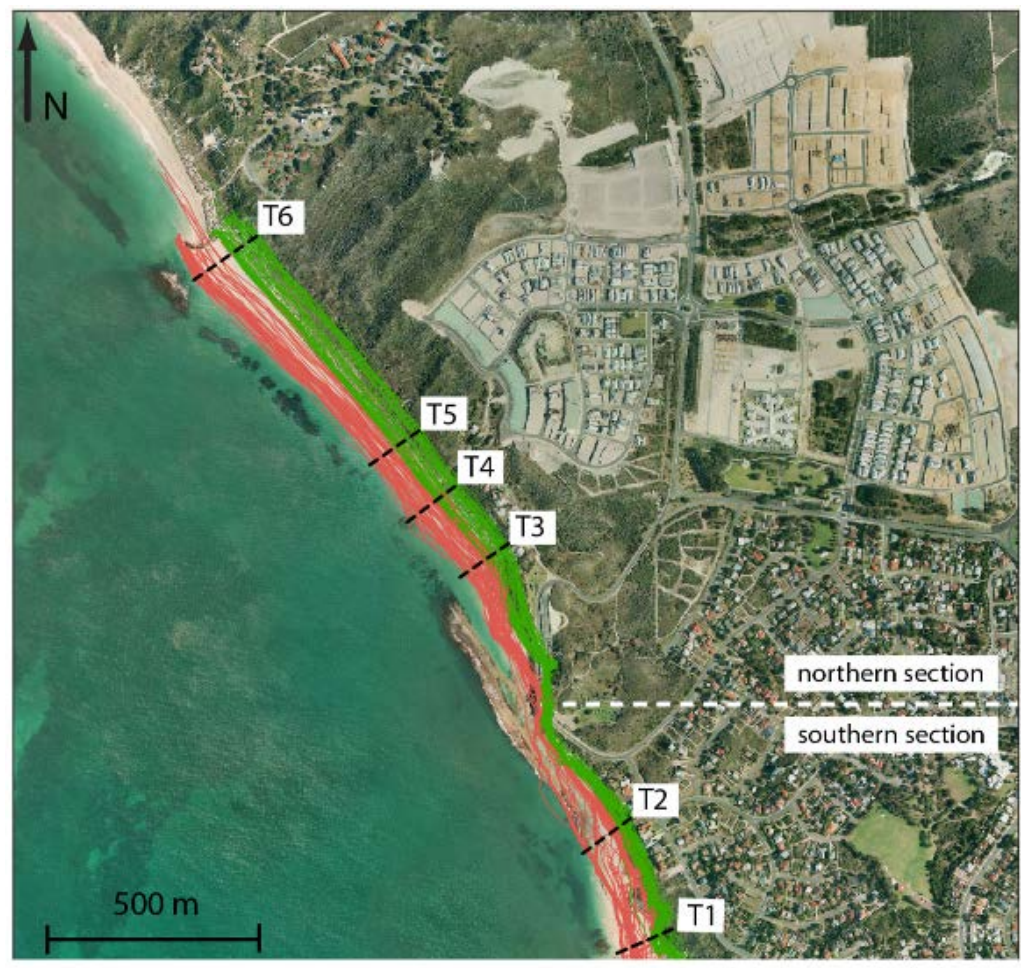

Figure 4. Vegetation lines (green) and instantaneous shorelines (orange) extracted from aerial photographs from 1971—2009, and transects where beach width was extracted (photo source: Landgate).

\section{Monthly and Seasonal Behavior}

Nine subaerial beach transects were surveyed monthly (Fig. 5a) from February 2010 to March 2012 (Fig. 3b), shown as T1 to T9 in Fig. 2b. In addition, five hydrographic surveys were undertaken to the 10 m-depth contour (Fig. 3b) in late summer and winter in: (1) February 2010; (2) September 2010; (3) March 2011; (4) September 2011; and (5) February 2012 (Fig. 5b). The vertical accuracy of the bathymetries derived from the hydrographic surveys was $\pm 0.38 \mathrm{~m}$ and differences between the surveys were calculated between the 6 monthly-periods. Sea level (Fig. 2a) was divided into its components: (1) MSL by calculating 30 day-running mean values; (2) tide using the T_Tide Harmonic Analysis Toolbox (Pawlowicz et al. 2002); and (3) storm surge, calculated as the difference between sea level and tide. The monthly cumulative of the $3 \mathrm{pm}$ wind speed in the cardinal directions (E-W and N-S) was calculated using the method of Eliot and Travers (2011).
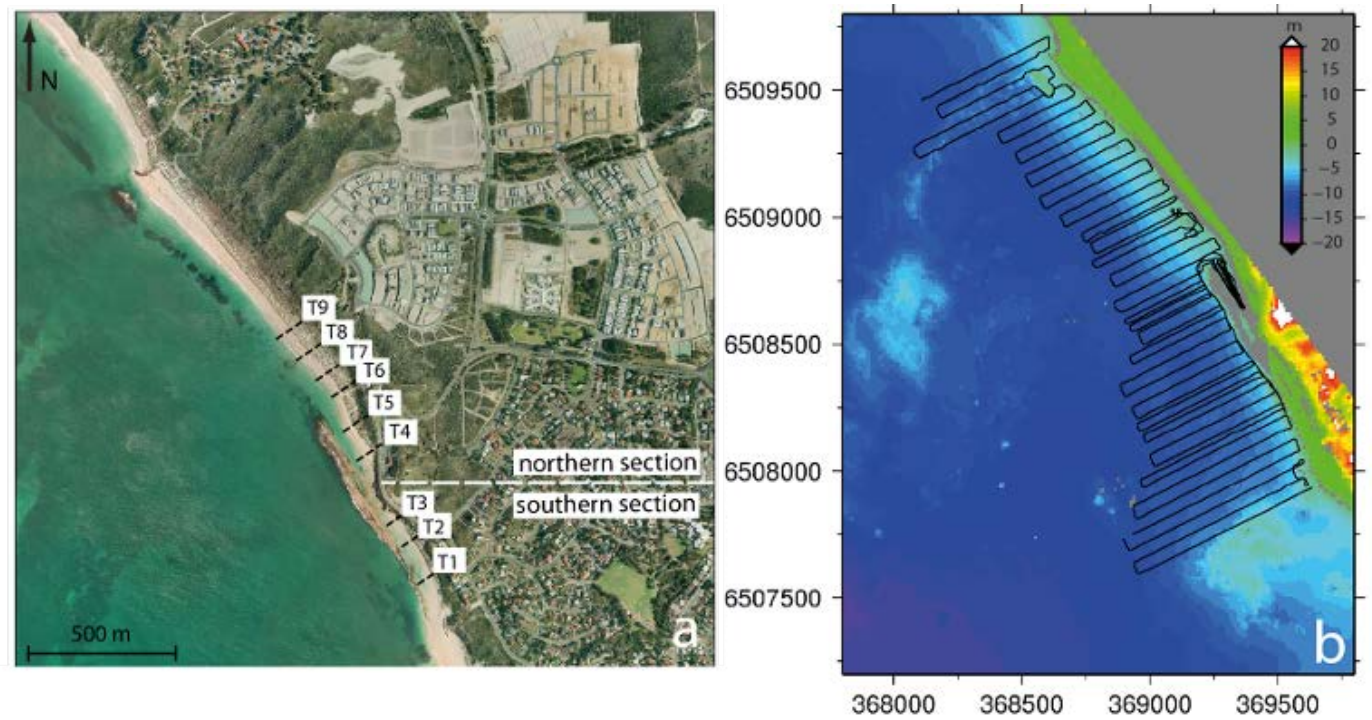

Figure 5. (a) Transects surveyed monthly; and (b) hydrographic survey track (bathymetry from Fugro, 2009). 


\section{Sea Breeze and Storm Events}

Field investigations under the action of sea breezes were undertaken from 1 to 5 February 2010 (Fig. 3b) and two subaerial beach profiles were surveyed every 2 hours: the Reef Profile (b) and the Exposed Profile (c) in Fig. 6b (Gallop et al. 2011a, b), which also correspond to T7 and T9 in Fig. 5a. Beach volumes were calculated above MSL for a $1 \mathrm{~m}$-wide transect, assuming uniform beach profile elevation 0.5 m either side. Two Acoustic Doppler Current Profilers (ADCPs) were deployed: offshore in $10 \mathrm{~m}$ water depth and $20 \mathrm{~m}$ seaward of the nearshore reef. Acoustic Doppler Velocimeters (ADVs) were deployed at the back of the surf zone fronting the two beach profiles (Fig. 5b) and five GPSdrifters were deployed in the lagoon.

The beach response to two consecutive storms was monitored from 8 to 14 July 2010 (Fig. 3b; Gallop et al., in press). The storms had approximately a 1-year return period according to $\mathrm{Li}$ et al. (2011). Three subaerial profiles were measured: the Bluff Profile (a), the Reef Profile (b), and the Exposed Profile (c) in Fig. 6b, which correspond to T3, T7 and T9 in Fig. 5a. ADVs were also deployed in the same locations as during the sea breezes (Fig. 6b).
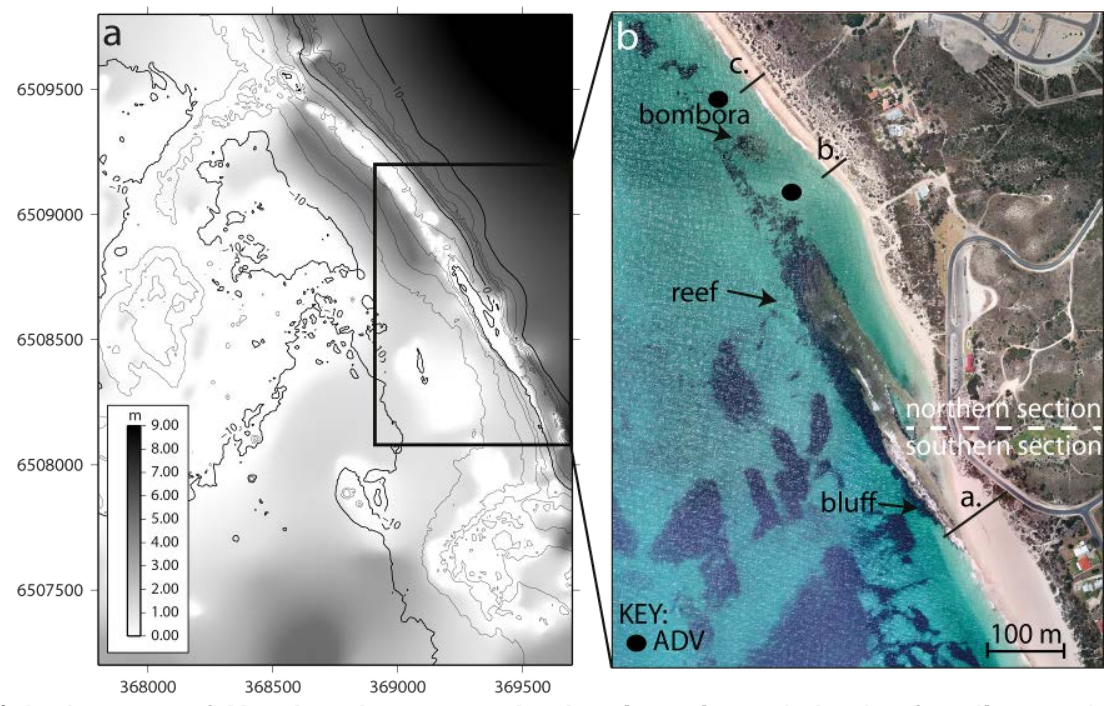

Figure 6. (a) bathymetry of Yanchep Lagoon: color bar is estimated depth of sediment above the rock substrate in February 2010 and white areas are limestone outcrops; and (b) subaerial beach profiles measured during sea breezes and storms: $a=E x p o s e d$ Profile, $b=R e e f$ Profile, and $c=B l u f f$ Profile (photo source: Nearmap).

\section{Single waves}

DualSPHysics (Crespo et al. 2011) was used to investigate the accretion process that occurs over the bluff during the sea breeze season in spring and summer (Bosserelle et al. 2011). This Smooth Particle Hydrodynamic (SPH) model uses a Lagrangian method to calculate the trajectories and interaction of fluid particles (Dalrymple and Rogers 2006). A simplified, scaled model of the Bluff Profile was used, with and without a sand ramp to seaward. The hydrodynamics were modelled for a range of MSLs, from present day to a rise of $1 \mathrm{~m}$, and waves were generated with a piston wave-maker equivalent to wave heights of 1.2 to $2.4 \mathrm{~m}$ in the field with a period of $15 \mathrm{~s}$. The water particle spacing was $0.007 \mathrm{~m}$ and each simulation was run for $30 \mathrm{~s}$.

\section{RESULTS}

\section{Inter-annual and Decadal Behavior}

There was strong alongshore variability in the inter-annual beach behavior. T1 was located to the south on a salient (Fig. 4) and the vegetation line, shoreline and beach width were relatively stable from 1970 to 2009. In contrast, at T2 where the beach was perched on the bluff that reached $0.4 \mathrm{~m}$ above MSL, there was considerable inter-annual variability in the beach width, with the shoreline varying within $100 \mathrm{~m}$ (Fig. 7e). T3 was located near the exit of the lagoon and it appeared that the vegetation line prograded since 1970 and inter-annual variability was low compared to T2. At T4 to T6 (Fig. 7a-c) the beach accreted after the installation of the groyne in 1971 and inter-annual variability was low 
compared to T2. Beach width on the northern and southern sides of the limestone headland varied inversely. Seaward movement of the shoreline and vegetation line occurred at T4 to T5 after the installation of the groyne (Fig. 2b) in 1971. The relationship between beach width and annual indices of the metocean forcings did not clearly correlate to indices of the annual wind anomaly, sea level or wave height (Fig. 8). Therefore, to explain the inter-annual variation in beach width it was necessary to go down in the temporal scale and investigate seasonal changes.
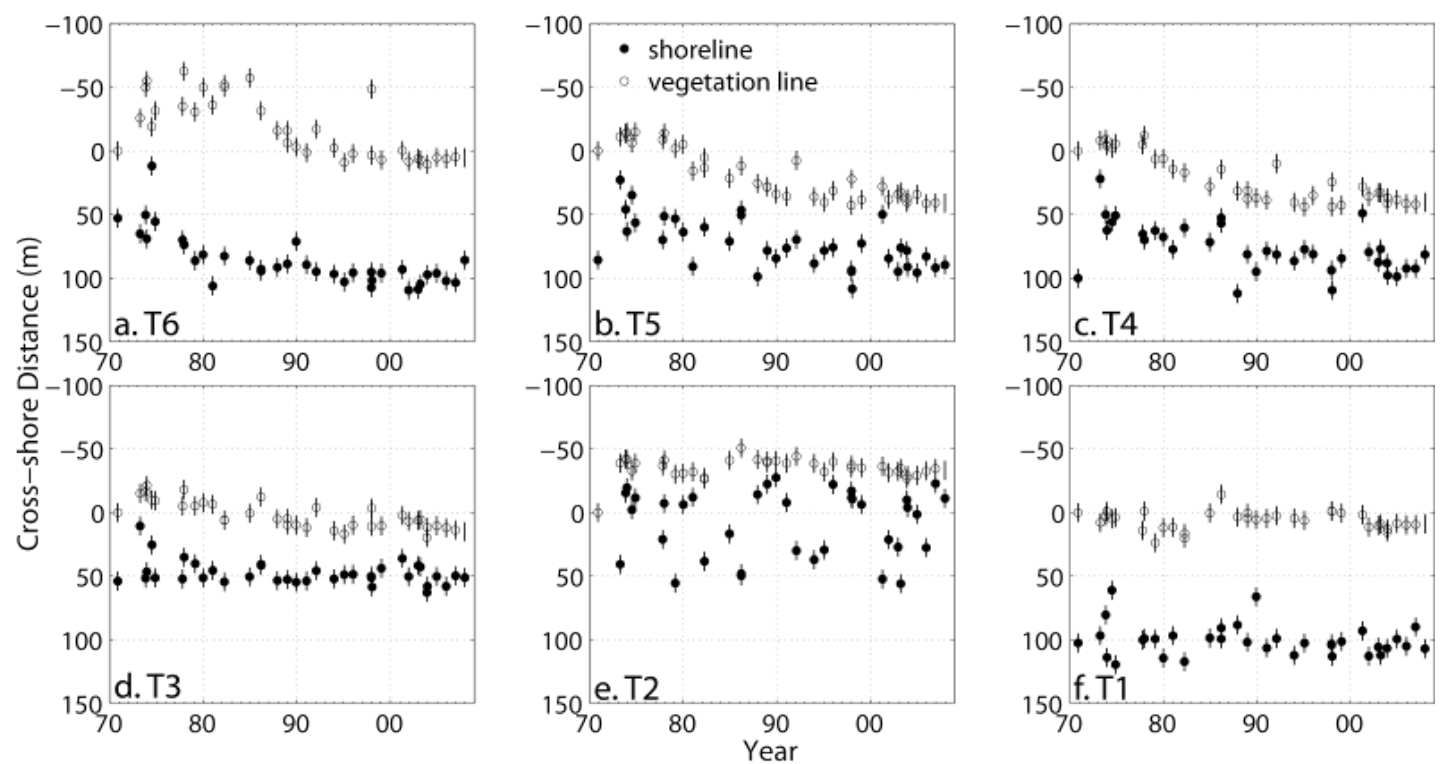

Figure 7. Vegetation lines and shorelines from 1971 to 2009 with the uncertainty.
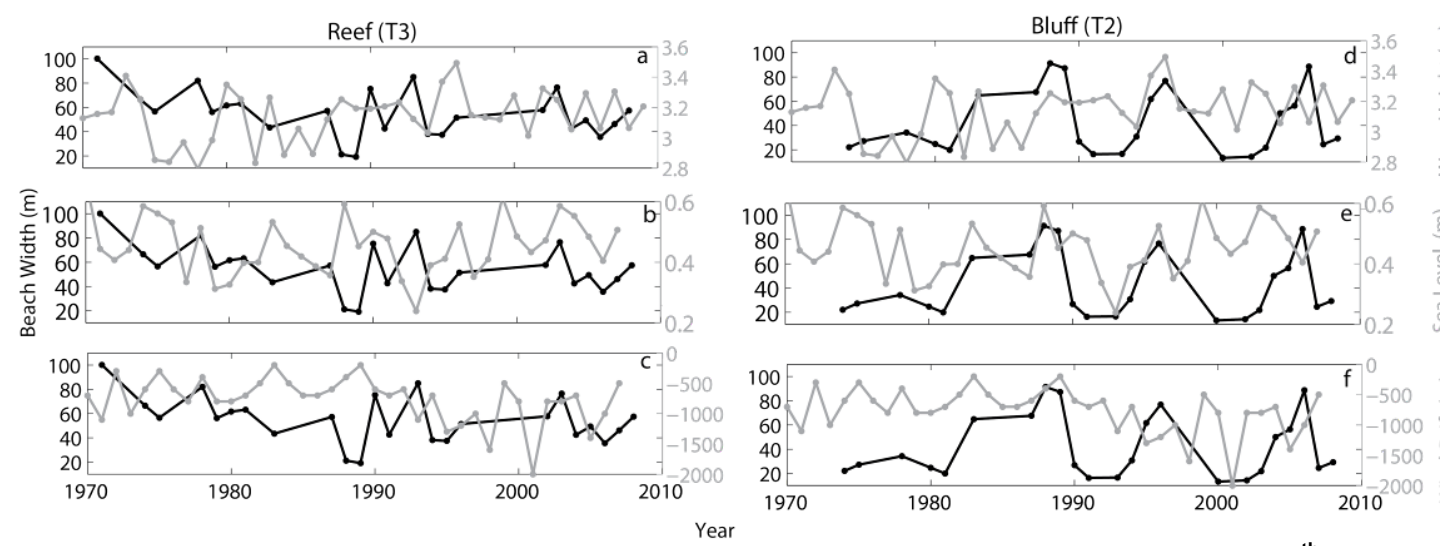

Figure 8. Beach width and annual metocean indices at T3 $(a-c)$ and T2 (d - f); (a) and (d) the $90^{\text {th }}$ percentile of wave height, (b) and (e) sea level (30 day-running mean $+99^{\text {th }}$ percentile of tides and storm surge); and (c) and (f) annual northerly wind drift.

\section{Monthly and Seasonal Behavior}

It was envisaged that longshore currents would play a key role in generating local sediment sources and sinks; and that the elevation of limestone landforms relative to sea level would determine spatial variability in erosion and accretion. Seasonal sediment fluxes revealed that there are four seasonal sediment cells that had consistent modes of seasonal sediment flux (Fig. 9a):

- the Bluff Cell extends from the stable salient at the south to the limestone headland and the beach was perched on the bluff that was $0.4 \mathrm{~m}$ above MSL;

- the Lagoon Cell extends northwards from the headland to what appeared to be the limit of the lagoon current jet. The beach is fronted by submerged reef that is continuous and $0.3 \mathrm{~m}$ below MSL in the southern part then changes to patchy submerged reef > 2 m-deep heading north;

- $\quad$ the Groyne Cell extends from the lagoon current to the groyne and the beach is fronted by patchy submerged reef $>2$ m-deep; and

- $\quad$ the Offshore Cell encompasses the entire area seaward of the three coastal cells (Fig. 9). 
During autumn and winter, the Bluff, Groyne and Offshore Cells eroded while the Lagoon Cell accreted (Fig. 9a and c). In spring and summer, the Bluff, Groyne and Offshore Cells accreted while the Lagoon Cell eroded (Fig. 9a and d). The contrast between the accreted state of the Bluff Cell and the eroded state is highlighted in Fig. 10. The boundary between the Bluff and Groyne Cells is at the limestone headland that traps northwards littoral drift in summer. The boundary between the Lagoon and Groyne Cells appears to be at the limit of the northwesterly current that comes out of the lagoon.
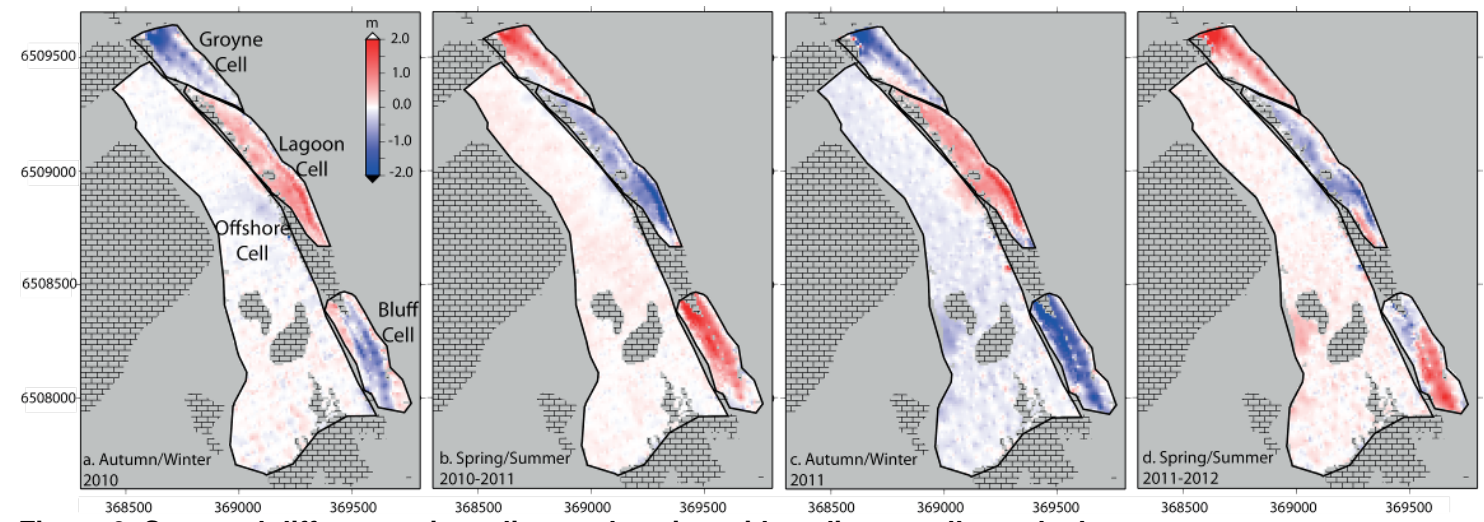

Figure 9. Seasonal differences in sediment elevation with sediment cells marked.
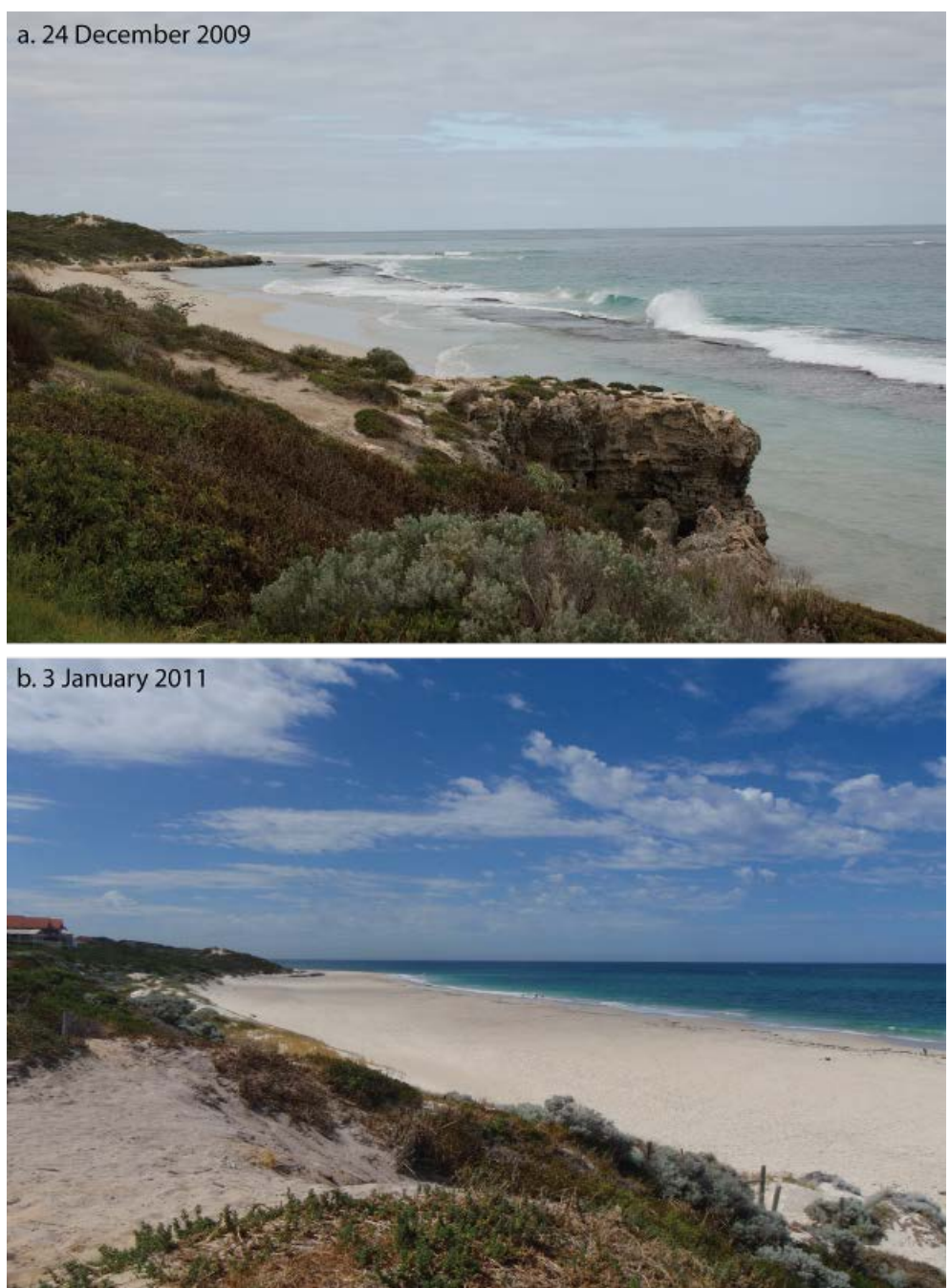

Figure 10. Bluff Cell at Yanchep Lagoon in (a) an eroded state with a coastal lagoon; and (b) an infilled state as a beach. 
Inter-annual variability in the magnitude of seasonal sediment fluxes appeared to be driven by a combination of forcings and their interaction with the limestone topography, including sediment supply, sea level and wave conditions. The dominant metocean-forcings of sediment transport at Yanchep Lagoon from 2010 to 2012 are shown in Fig. 11. Cumulative 3 pm daily wind speed is a proxy for littoral drift in summer, and is strongly southerly in spring and summer with the longshore component reducing in winter (Fig. 11a). The longshore component of sea is more southerly in spring and summer during sea breezes, then can become northerly in winter (Fig. 11b). Generally, there are more storm surges in winter (Fig. 11c) and MSL is higher is autumn and winter than in summer (Fig. 11d).

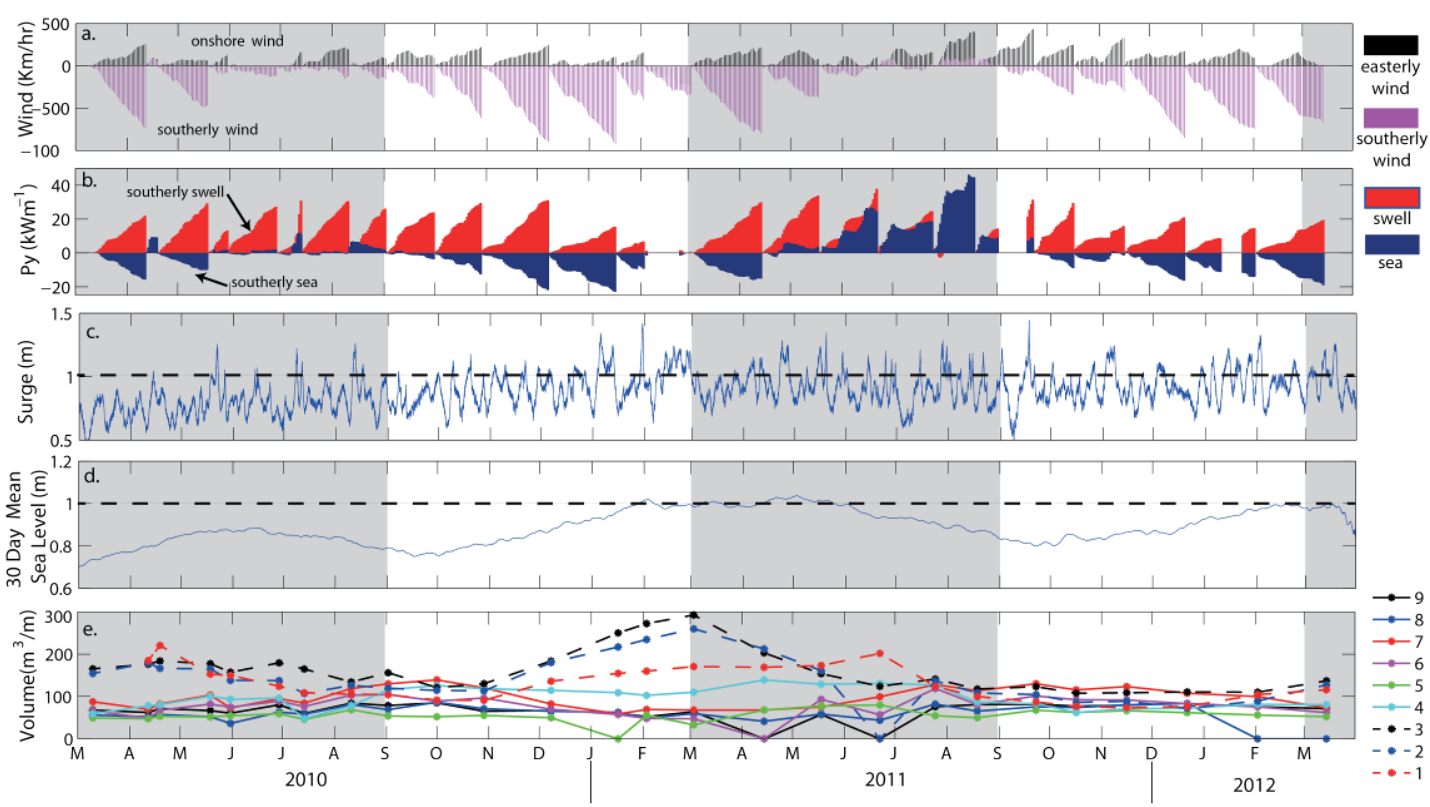

Figure 12. (a) monthly cumulative of $3 \mathrm{pm}$ winds; (b) monthly cumulative longshore component of $3 \mathrm{pm}$ wave power; (c) storm surge where dashed line is at $1 \mathrm{~m}$; (d) 30 day-running mean of sea level (CD); and (e) subaerial beach profile volume at $\mathrm{T} 1$ to $\mathrm{T} 9$.

Inter-annual variability in sediment fluxes in the Lagoon and Groyne Cells appeared to be largely driven by sediment supply from the Bluff Cell. The Bluff Cell was highly sensitive to inter-annual variability in the forcing conditions (Fig. 11e). In winter 2011 (Fig. 9c), there was four times the erosion $\left(94,000 \mathrm{~m}^{3}\right)$ of winter $2010\left(23,000 \mathrm{~m}^{3}\right)$ (Fig. 9a) in the Bluff Cell. This large volume of eroded sediment travelled north in the lagoon and supplied the Lagoon Cell in winter 2011, which consequently accreted by $68,000 \mathrm{~m}^{3}$ in winter 2011 compared to 55,000 $\mathrm{m}^{3}$ in 2010 . Also, in summer 2011 to 2012, in the Bluff Cell (Fig. 9d) there was only half the accretion $\left(36,000 \mathrm{~m}^{3}\right)$ of the previous summer when this cell accreted by $69,000 \mathrm{~m}^{3}$ (Fig. 9b). This led to the Lagoon Cell eroding by only half as much as the previous summer because the main sediment transport pathway from the Bluff via the Lagoon was not fully blocked. Seasonal sediment fluxes were relatively constant in the Groyne Cell that gained 40,000 to $50,000 \mathrm{~m}^{3}$ of sediment in summer by trapping littoral drift, then eroding in winter during northwesterly storms. In the Offshore Cell, while it appeared to consistently erode in winter and accrete in summer, the normalized seasonal sediment fluxes were an order of magnitude lower than in the coastal cells (Fig. 9) and are here forth omitted from discussion.

\section{Sea Breeze and Storm events}

Sea Breezes

Overall, the Reef Profile had larger fluxes in sediment volume throughout the cycle of the sea breezes than the Exposed Profile (Fig. 13b) (Gallop et al., 2011a, b). This was likely because of the fast current jet exiting the lagoon. Also, the Exposed Profile consistently recovered more overnight (Fig. 13b). Despite being just $120 \mathrm{~m}$ apart, the profiles did not always have the same mode of sediment transport. For example, on 3 February the Exposed Profile was stable during the sea breeze and on 4 February it eroded. In contrast, the Reef Profile accreted on both days (Fig. 13b). This accretion was probably due to weaker lagoon currents on 3 and 4 February due to relatively weak sea breezes (Fig. 13a) which allowed incident waves to transport sediment onshore rather than it being diverted offshore 
by the jet. Cross-shore currents in the surf zone fronting the reef tended to be faster and more onshore than at the surfzone fronting the exposed profile due to the lagoon jet forcing currents to turn shoreward.

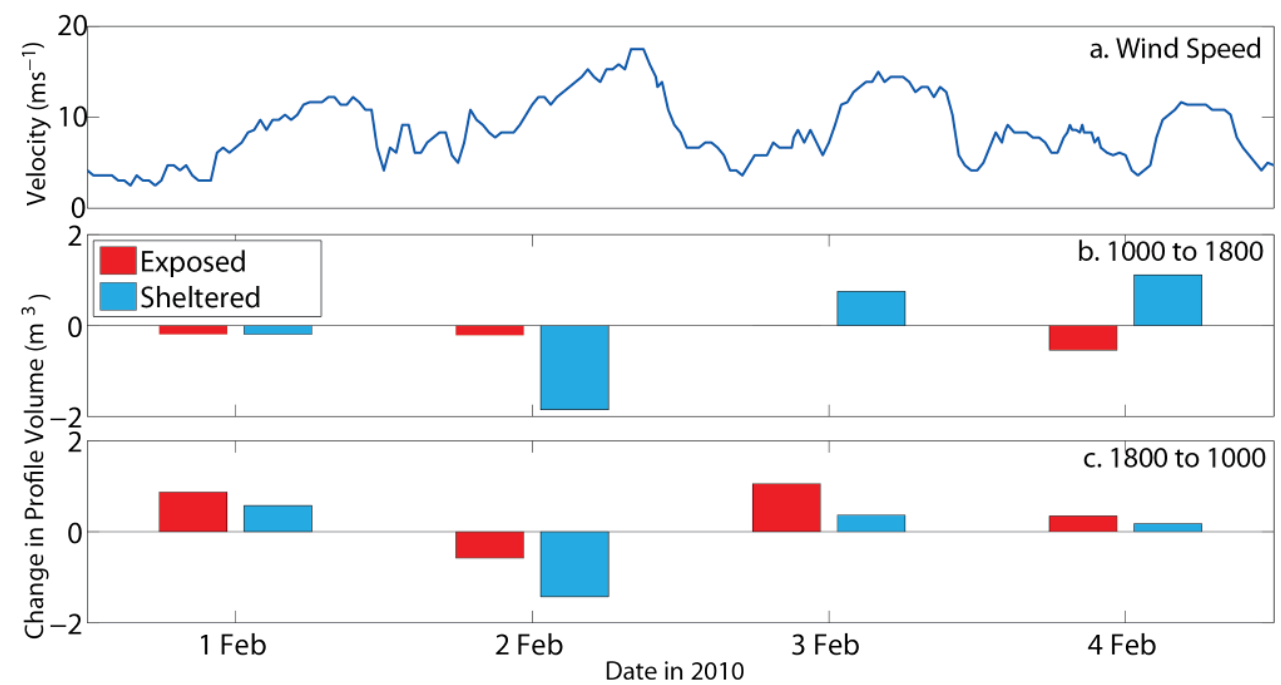

Figure 13. (a) wind speed, (b) total beach profile volume change per unit $\mathrm{m}$ of beach width between $1000 \mathrm{~h}$ and $1800 \mathrm{~h}$; and (c) total beach profile volume change overnight between 1800 and $0800 \mathrm{~h}$ (modified from Gallop et al., 2011b).

Storms

Between July 8 and 9 all three subaerial profiles eroded after the storm onset (Fig. 14). Similar volumes of erosion occurred at the Exposed and Bluff Profiles, with less than half this at the Reef Profile (Fig. 14c). Between July 9 and 10, the Exposed Profile accreted slightly whilst the other two eroded slightly. On July 10 and 11 between the two storm fronts, all three profiles were relatively unchanged. When the second storm front arrived, the Exposed Profile eroded by $45 \mathrm{~m}^{3} \mathrm{~m}^{-1}$ so that the entire subaerial beach profile was eroded with a 2m-high scarp cut into the dune. There was almost 15 $\mathrm{m}^{3} \mathrm{~m}^{-1}$ erosion at the Reef Profile and almost no change at the Bluff Profile. Following the second storm, all three profiles were relatively stable until the end of the monitoring period (Fig. 14c). During the storms, the Exposed Profile eroded by $13 \mathrm{~m}^{3} \mathrm{~m}^{-1}$ (lost 22\% of the pre-storm profile volume) whilst the Reef Profile was relatively stable. The Bluff Profile eroded by $12 \mathrm{~m}^{3} \mathrm{~m}^{-1}$ (lost $11 \%$ of the pre-storm volume).

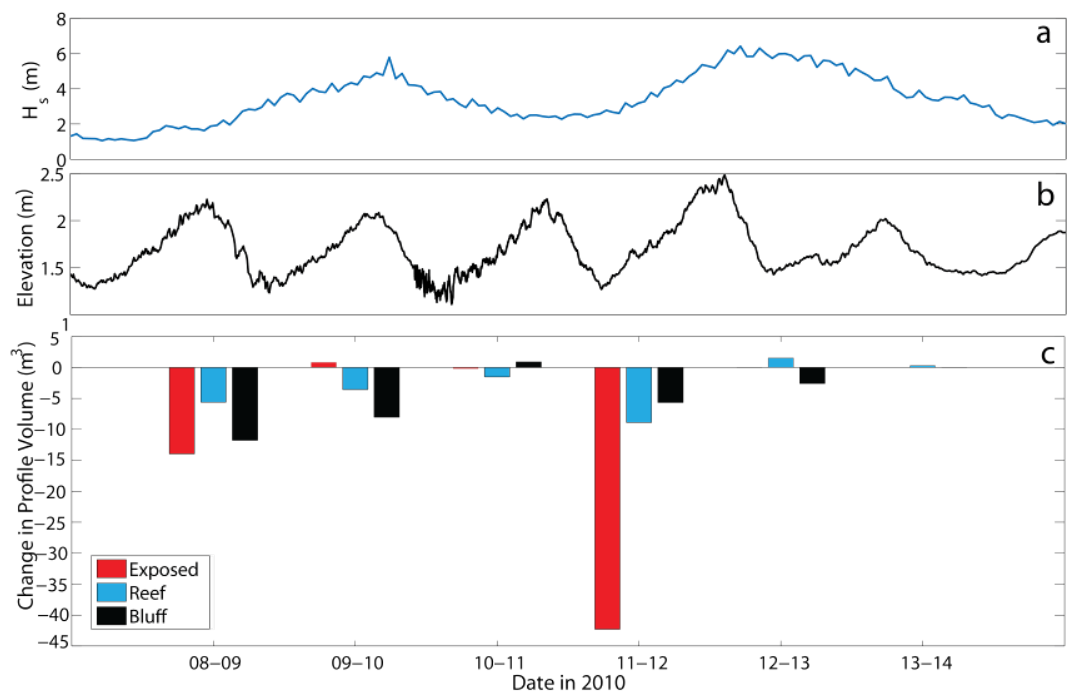

Figure 14. (a) offshore wave height; (b) sea level in the surf zone; and (c) daily change in volume of subaerial beach profile between $1600 \mathrm{~h}$ (low tide was at 1700) during storms in July 2010 (modified from Gallop et al., in press). 


\section{Single waves}

To investigate potential mechanisms of accretion during spring and summer of the beach in the Bluff Cell (Fig. 9a), sediment transport across an idealized cross-shore bluff profile was modelled (Bosserelle et al. 2011) using DualSPHysics (Crespo et al. 2011).

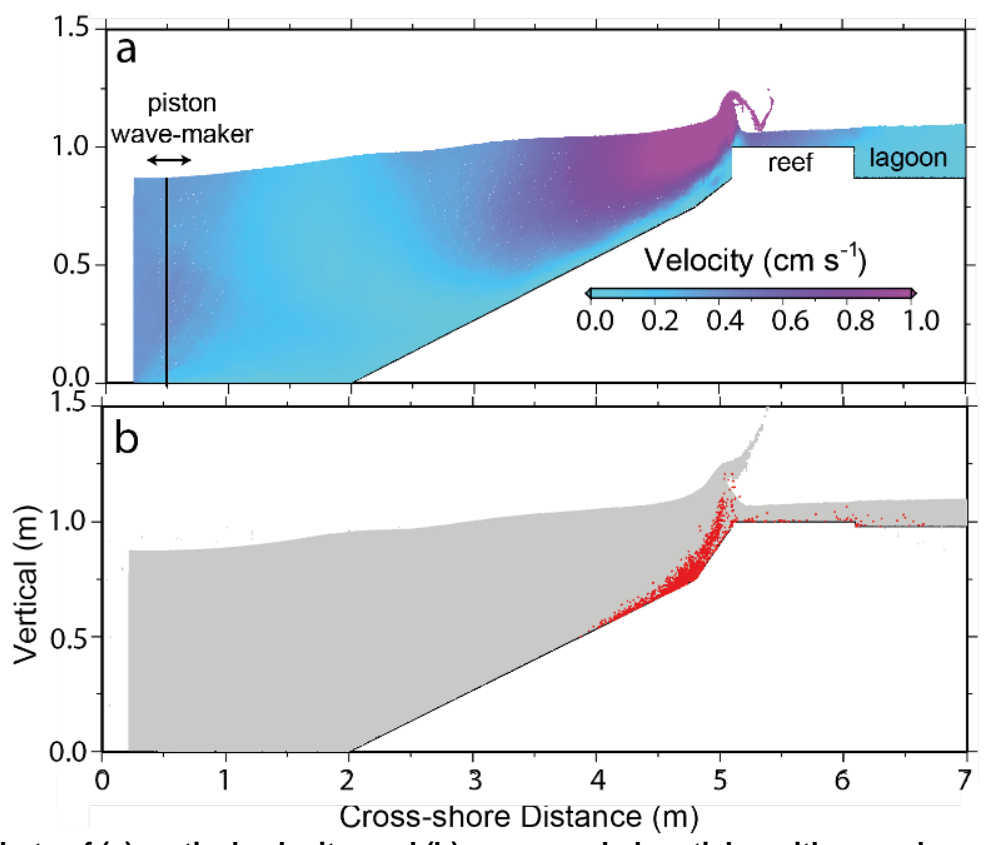

Figure 15. Snapshots of (a) vertical velocity; and (b) resuspended particles with a sand ramp modeled with DualSPHysics.

The bluff had a near-vertical slope and was several meters above the sand, reaching $0.4 \mathrm{~m}$ above MSL (Fig. 15a). The profile consisted of a narrow, shallow lagoon, a shallow reef platform and sometimes a sand ramp fronting the bluff. The model revealed complex flow structures as waves steepened and broke on the bluff and created a reflected wave. As the bore hit the bluff, the vertical velocity reached the equivalent of $2.2 \mathrm{~m} \mathrm{~s}^{-1}$ at the field scale (Fig. 15b). There was also a velocity pulse near the sea bed of more than $0.6 \mathrm{~m} \mathrm{~s}^{-1}$ which was present for all modelled MSLs. In addition, the pulse was present for every wave including the first one which suggests that it is not a result of interaction with the reflected wave. This velocity pulse resulted in a resuspension event in the sand transport simulation. However the presence of the bluff impeded the flow of sand to the lagoon. The presence of a sand ramp fronting the bluff facilitated somewhat the transport of sand in the lagoon (Fig. 15b).

\section{DISCUSSION}

It was hypothesised that limestone landforms with a higher elevation relative to sea level would be more likely to reduce coastal erosion but inhibit beach recovery after erosive periods; and that currents constricted by the limestone landforms would play a key role in beach morphodynamics by creating local sources and sinks of sediment. Therefore, an investigation of sediment transport over multiple temporal and spatial scales was undertaken at Yanchep Lagoon in southwestern Australia, where the sandy beaches are perched on calcarenite limestone landforms. Scales included: (1) micro-scale (single waves); (2) meso-scale (storms and sea breezes); (3) macro-scale (seasons); and (4) mega-scale (years and decades).

Results showed that investigating sediment transport at a single scale does not facilitate a full understanding of how sediment transport interacts with hard landforms. For example, the relatively high inter-annual variability in beach width over the bluff that reached $0.4 \mathrm{~m}$ above MSL (Fig. 7e) did not clearly correspond to annual indices of sea level, waves and wind drift which was a proxy for littoral drift (Fig. 8d, e, f). Therefore, analysis of monthly and seasonal changes in beach morphology was able to resolve the processes that drove the inter-annual variation. Also, to identify the process of sediment overtopping of the limestone reef in summer that was revealed in seasonal surveys, numerical modelling of sediment transport during a single wave with SPH were used. This revealed the pulses in vertical velocity when a wave hits the bluff, and that a sediment ramp seaward of the bluff is required (Fig. 15). 
This shows the importance and necessity of multi-scale investigations to get a full understanding of how coastal sediment transport interacts with hard landforms.

Below, first we discuss how the elevation of limestone landforms relative to sea level influences beach erosion and recovery; then how the placement and continuity of landforms influences coastal sediment transport. This is followed by discussion of how hard landform geometry results in spatial and temporal variability in coastal sediment transport then recommendations are given for future research.

\section{Hard Landform Elevation}

At Yanchep Lagoon, the presence of limestone landforms and their elevation relative to sea level determined if, and how much, they influenced beach erosion and recovery. Examples of how hard landform elevation influences these two processes are discussed here:

- Reduced erosion: Hard landforms with higher elevation relative to sea level appear to more greatly reduce beach erosion. For example, during the storm in July 2010, the Exposed Profile that was not fronted to seaward by limestone outcrops eroded the most with a 2 m-high scarp cut into the dune. This is because higher landforms have higher thresholds for sea level and wave run-up before beach erosion occurs.

- Inhibited recovery: It appeared that landforms with higher elevation can also inhibit onshore sediment transport and therefore beach recovery. For example, during the storms in July 2010, while the subaerial Reef Profile was dynamic throughout, overall there was no change in beach profile volume. This was because when storm conditions decreased for short periods during the week-long monitoring programme, short periods of accretion buffered the beach profile from erosion. In contrast, this did not occur at the Bluff Profile. Also, in the month after the storm, while the Exposed Profile had largely recovered, recovery was much slower at the Bluff Profile. Numerical modeling on an idealized bluff suggested that a sand-ramp is necessary for sediment to overtop the bluff and accrete on the beach. While this likely occurs in summer when littoral drift is strong (Tonk 2004), it is unlikely to occur in winter due to: (1) a lack of littoral drift and therefore sediment supply for ramp formation; and (2) the fast lagoon current likely transports much suspended sediment northwards rather than depositing it seaward of the bluff (this is discussed in detail below). Recovery in the month after the storms at the Exposed and Reef Profiles appeared to be aided by the formation of a sand-bar during the storms. Therefore, recovery of beaches perched on hard landforms with a relatively high elevation require sufficient sediment supply and appropriate hydrodynamic conditions for the formation of sand-ramps to seaward to allow beach recovery.

\section{Hard Landform Placement and Continuity}

At Yanchep Lagoon, there are several processes through which the placement and continuity of the limestone landforms influences sediment transport. Landforms with particular spatial configurations in the nearshore can:

- Trap littoral drift: Hard landforms can protrude from the coast into the path of littoral drift. At Yanchep, this was observed at the groyne and the limestone headland that trapped northerly littoral drift in summer. The headland formed a boundary between seasonal sediment cells where the updrift section of beach in the Bluff Cell accreted in summer while the beach in the downdrift Lagoon Cell eroded.

- Create local sediment sources and sinks: The continuous limestone reef (Fig. 6b) was located parallel to shore was elevated to $0.3 \mathrm{~m}$ below MSL. This reef impounded a coastal lagoon with the shore. Current jets formed in this lagoon and created local sediment sources (from the Bluff Cell) and sinks (in the Lagoon Cell). The patchy reefs located north of the lagoon were fully submerged with elevation of more than $2 \mathrm{~m}$ below MSL. These reefs were insufficiently high and too patchy to impound the lagoon current which turns northwest after is exits the lagoon. It appeared that this current may have aided recovery of the Reef Profile for short periods during the July 2010 storms, and in the following month. However, during sea breezes in February 2010 it appeared that overnight recovery was inhibited when the lagoon current was faster due to strong sea breezes. This current was also responsible for transporting sediment eroded from the Bluff Cell in winter to the Lagoon Cell and allowing the beach to accrete.

- Create erosion hotspots: Alongshore variation in reef continuity created erosion 'hotspots' where the beach was not fronted to seaward by limestone outcrops. For example, during the storm in July 2010 at the Exposed Profile (Fig. 6b) beach erosion was severe and a 2 m-high scarp was cut into 
the dune while in comparison, the Bluff and Reef Profiles (Fig. 6b) has less beach erosion and the dunes were stable.

\section{Origins of Spatial and Temporal Variability}

The mechanisms described above were responsible for creating temporal and spatial variability in the beach behaviour. Below, we discuss some of the key observations of temporal and spatial variability and the causes.

\section{Temporal Variability}

- $\quad$ Sediment supply: Sediment supply played a key role in determining sediment fluxes in the Bluff Cell by allowing the formation of a sand ramp. Then sediment could travel up this ramp allowing the lagoon to infill and the beach to accrete. Strong southerly winds in spring and summer are an indicator of more littoral drift in spring and summer 2010 to 2011 compared to 2011 to 2012 (Fig. 12a). This was reflected by 50 \% more accretion in the Bluff Cell in summer 2010 to 2011.

- Relative elevation of hard landform to sea level: As described above, the relative elevation of hard landforms to sea level determines if and how much beach erosion and accretion are dampened. Temporal variations in sea level therefore play an important role. For example, in winter 2011 MSL was $0.2 \mathrm{~m}$ higher than in 2010. Consequently, in winter 2011 there was four times the erosion in the Bluff Cell (Fig. 9c) compared to winter 2010 (Fig. 9a). This eroded sediment resulted in a greater sediment supply to the Lagoon Cell in winter 2011 which consequently accreted more.

- Lack of buffering: The elevation of limestone landforms therefore determines the 'buffering' ability of beach profiles. At the seasonal scale, similar to at the inter-annual scale, the most inter-annual variability in seasonal sediment flux occurred on the beach perched on the bluff (Fig. 9). Results from sea breeze and storm experiments suggest that hard landforms with higher elevation relative to sea level, such as the bluff, are more likely to inhibit onshore sediment transport. The bluff appeared to prevent the formation of sand-bars and required a sand-ramp to enable sediment to overtop the bluff and accrete on the beach. Therefore, there is no significant 'buffering' system where periods of accretion can help reduce the impact of erosion events. This is a likely cause for the high degree of inter-annual and seasonal variability in sediment fluxes in the Bluff Cell.

- Strength of lagoon current: During sea breezes, variations in wind wave conditions appeared to correspond to variability in the speed of the lagoon current. It appeared that fast lagoon currents during stronger sea breezes inhibited overnight recovery of the Reef Profile. In contrast, weakened lagoon currents during weaker sea breezes appeared to allow incident waves to transport some sediment onshore, rather than all of it being transported offshore by the current jet.

Spatial Variability

- Placement and continuity of hard landforms: Spatial variability in sediment fluxes was observed at all scales. At the seasonal scale, there were 3 coastal sediment cells (Fig. 9). The boundaries between the cells were based on the seasonal mode of sediment transport. The mode on each cell was determined ultimately by the placement and continuity of the limestone landforms. The boundary between the Bluff and Lagoon Cells was formed by the limestone headland (Fig. 2b), that trapped northerly littoral drift in summer. The boundary between the Lagoon and Groyne Cells was where the longshore current in the lagoon, converged with southerly currents from the groyne. In addition, local sediment sources and sinks created by the lagoon current also played a key role in causing erosion of updrift areas and accretion of downdrift areas during storm events and seasonally.

- Hard landform elevation: During sea breeze and storm events, the mode and magnitude of sediment transport varied within just tens of meters. This was in part related to the elevation and continuity of the limestone landforms through the mechanisms described above in the section about the effect of hard landform elevation.

\section{Future Research}

This research confirmed the importance of several distinct processes in determining sediment transport on perched beaches (Fig. 1), including trapping of littoral drift; development of scour-holes and sediment ramps; wave attenuation and dampened offshore sediment flux, and current jets that create local sediment sources and sinks. However, the influence of hard landforms on the groundwater table was not addressed. It is likely that alongshore spatial variation in rock topography, such as depth below 
the sediment and distance seaward also create alongshore variability in sediment transport and may create erosion hotspots.

Using numerical modelling to separate the importance of cross-shore and longshore processes would be advantageous. For example, to determine if during the July 2010 storms, was the recovery of the Reef Profile relatively high because the submerged reefs did not significantly inhibit onshore sediment transport?; or was the recovery mainly because of the local supply of sediment from the Bluff Cell through the lagoon?

We showed that sea level relative to structure elevation plays an important role in determining magnitudes of coastal erosion and accretion. With a rise in relative sea level, coasts perched on hard landforms that were previously stable during potentially erosive events, may start to erode, threatening infrastructure, recreational amenities and communities. This is particularly an issue on low-lying coasts such as on coral atolls where beach and island stability is determined by beachrock and coral landforms. There needs to be more research on mapping low-lying and built-up coasts that are perched on hard landforms, and on categorizing factors such as landform elevation and continuity. This will aid in focusing research effort and in coastal planning.

\section{CONCLUSIONS}

Interactions between sediment transport and the calcarenite landforms at Yanchep Lagoon in southwestern Australia were investigated over a cascade of spatial and temporal scales: from single waves, through sea breeze and storm events, to seasonal and inter-annual changes. The hypotheses that were confirmed included:

- hard landforms with higher elevations relative to sea level are more likely to reduce coastal erosion but also to inhibit recovery; and

- the placement and continuity of hard landforms plays a key role in sediment transport by determining the formation of current jets and therefore local sediment sources and sinks.

These hypotheses were consistently confirmed at all scales, however results show that to fully explain changes at broader scales (such as inter-annual and seasonal changes) an understanding at finer scales (such as during sea breezes, storm events and single waves) was necessary.

\section{ACKNOWLEDGEMENTS}

For field work funding and data thank you to the Western Australian Marine Science Institution (WAMSI, Project 6.1); the Department of Transport; Fugro, Landgate; Nearmap; the Bureau of Meteorology; the field work team and the Samaha Research Fellowship. For funding ICCE conference attendance thanks to the UWA Research Collaboration Awards; UWA Grants for Research Student Training scheme; and the BankWest Postgraduate Research Travel Award.

\section{REFERENCES}

Boak, E.H., and I.L. Turner. 2005. Shoreline definition and detection: A review. Journal of Coastal Research, 21(4), 688-703.

Bosserelle, C., I.D., Haigh, C. Pattiaratchi C, and S. Gallop. 2011. Simulation of Perched Beach Accretion using Smoothed Particle Hydrodynamics. Proc of Coasts and Ports, Perth, Australia.

Bosserelle, C., C. Pattiaratchi, and I.D. Haigh. 2012. Inter-annual variability and longer-term changes in the wave climate of Western Australia between 1970 and 2009. Ocean Dynamics, 62, 63-76.

Crespo, A.J.C., J.M. Dominguez, M. Gómez-Gesteira, A. Barreiro, and B.D. Rogers. 2011. User Guide for the DualSPHysics Code v1.0, http://www.dual.sphysics.org.

Dalrymple, R.A., and B.D. Rogers. 2006. Numerical modeling of water waves with the SPH method. Coastal Engineering, 53, 141-147.

Department of Defence, 2012. Australian National Tide Tables 2012. Australian Hydrographic Publication 11, Canberra.

Eliot, M., and A. Travers. 2011. Dynamics of Scarborough Beach, City of Stirling, Western Australia. Proceedings of Coasts and Ports, 28-30 September, Perth, Australia.

Fugro, 2009. LADS Mk II Metadata Statement, Western Australia, Two Rocks to Cape Naturaliste, Bathymetry and Seabed Survey, LiDAR - April/May 2009. Adelaide, Australia.

Gallop, S.L., C. Bosserelle, C. Pattiaratchi, and I. Eliot. 2011a. Hydrodynamic and morphological response of a perched beach during sea breeze activity. Journal of Coastal Research, Special Issue 64, 75-79. 
Gallop, S.L., C. Bosserelle, C. Pattiaratchi, and I. Eliot. 2011b. Rock topography causes spatial variation in the wave, current and beach response to sea breeze activity. Marine Geology, 290, 29-40.

Gallop, S.L., F. Verspecht, and C. Pattiaratchi. 2012. Sea breezes drive currents on the inner continental shelf off southwest Western Australia. Ocean Dynamics, 62, 569-583.

Gallop, S.L., Bosserelle, C., Pattiaratchi, C., Eliot, I., in press. The influence of coastal limestone landforms on storm erosion and recovery of a perched beach. Continental Shelf Research. DOI: 10.1016/j.csr.2012.08.001.

Gentilli, J. 1972. Australian Climate Patterns. Thomas Nelson Ltd, Sydney.

Haigh, I.D., M. Eliot, and C.B. Pattiaratchi. 2010. Historic changes in storm surges around southwestern Australia. Proceedings of the 15th Physics of Estuaries and Coastal Seas (PECS) conference, 14-17 September, Colombo, Sri Lanka

Haigh, I.D., M. Eliot, and C. Pattiaratchi. 2011a. Global influences of the 18.61 year nodal cycle and 8.85 year cycle of lunar perigee on high tidal levels. Journal of Geophysical Research, 116, C06025, doi:10.1029/2010JC006645

Haigh, I.D., M. Eliot, C. Pattiaratchi, and T. Wahl. 2011b. Regional changes in mean sea level around Australia between 1897 and 2008. Proc of Coasts and Ports, 28-30 Sept, Perth, Australia.

Kempin, G.M. 1953. Beach sand movements at Cottesloe, Western Australia. Journal of the Royal Society of Western Australia, 37, 35-60.

Komar, P.D. 1991. Beach processes and sedimentation. Third Ed. Prentice Hall, New Jersey.

Larson, M., and N.C. Kraus. 1995. Prediction of cross-shore sediment transport at different spatial and temporal scales. Marine Geology, 126, 111-127.

Lemm, A., B. Hegge, and G. Masselink. 1999. Offshore wave climate, Perth (Western Australia), 1994-96’. Marine and Freshwater Research, 50(2), 92-102.

Li, F., C. Bicknell, C., and R. Lowry. 2011. Extreme analysis for offshore Perth, 1994-2010. Proceedings of Coasts and Ports, 29-30 September, Perth, Australia.

Masselink, G. 1996. Sea breeze activity and its effect on coastal processes near Perth, Western Australia. Journal of the Royal Society of Western Australia, 79, 199-205.

Masselink, G., and C.B. Pattiaratchi. 2001. Seasonal changes in beach morphology along the sheltered coast of Perth, Western Australia. Marine Geology, 172, 243-263.

Morton, R.A., and K.K. McKenna. 1999. Analysis and projection of erosion hazard areas in Brazoria and Galveston Counties, Texas. Journal of Coastal Research, Special Issue 28, 106-120.

Muñoz-Perez, J.J., and R. Medina. 2010. Comparison of long-, medium- and short-term variations of beach profiles with and without submerged geological control. Coastal Enging., 57, 241-251.

Murphy, P. 2011. A study of a shoreline salient formed due to a limestone reef at Yanchep Lagoon, Western Australia. Honors Dissertation, The University of Plymouth, U.K.

Pattiaratchi, C., and M. Eliot. 2009. Sea level variability in south-west Australia: From hours to decades. Proc. of the $31^{\text {st }}$ International Conf. on Coastal Engineering, Hamburg, Germany.

Pawlowicz, R, B. Beardsley, and S. Lentz. 2002. Classical tidal harmonic analysis including error estimates in MATLAB using T_Tide. Computers and Geosciences, 28, 929-937.

Playford, P.E., R.N. Cope, A.E. Cockbain, G.H. Low, D.C. Lowry. 1975. Phanerozoic, in, Geology of Western Australia: Mem. 2, pp. 223-433, Geological Survey of Western Australia, Australia.

Rey, D., B. Rubio, A.M. Bernabeu, and F. Vilas. 2004. Formation, exposure, and evolution of a highlatitude beachrock in the intertidal zone of the Corrubedo complex (Ria de Arousa, Galicia, NW Spain). Sedimentary Geology, 169, 93-105.

Semeniuk, V, and D.P. Johnson. 1982. Recent and Pleistocene beach/dune sequences, Western Australia. Sedimentary Geology, 32, 301-328.

Senechal, N., S. Abadie, E. Gallagher, J. MacMahan, G. Masselink, H. Michallet, A. Reniers, et al. 2011. The ECORS-Truc Vert'08 nearshore field experiment: presentation of a three-dimensional morphologic system in a macro-tidal environment during consecutive extreme storm conditions. Ocean Dynamics, 61(12), 2073-2098.

Steedman, R.K., P.D. Craig. 1983. Wind-driven circulation of Cockburn Sound. Australian Journal of Marine and Freshwater Research 34, 187-212.

Tonk, A.M.. 2004. Longshore sediment transport driven by sea breezes on low-energy sandy beaches, Southwestern Australia. PhD Thesis. Department of Geography. Loughborough, UK, Loughborough University. 
Verspecht, F., and C. Pattiaratchi. 2010. On the significance of wind event frequency for particulate resuspension and light attenuation in coastal waters. Continental Shelf Research, 30, 1971-1982. 